Pendas : Jurnal IImiah Pendidikan Dasar, ISSN Cetak : 2477-2143 ISSN Online : 2548-6950

Volume VI Nomor 01, Juni 2021

\title{
PENGARUH PENGGUNAAN MEDIA PEMBELAJARAN LAGU TERHADAP KEAKTIFAN SISWA DAN HASIL BELAJAR SISWA DI KELAS 3 SD KRISTEN SAINT JOHN BEKASI
}

\author{
Donald Samuel Slamet Santosa ${ }^{1}$, Mikhael Christupar ${ }^{2}$ \\ ${ }^{12}$ PGSD Fakultas Humaniora, Universitas Presiden \\ 1'dsamuel@president.ac.id, ${ }^{2 m i k h a e l c h r i s t 184 @ g m a i l . c o m ~}$
}

\begin{abstract}
This research departs from the problem of the poor quality of online learning carried out by teachers since the Covid-19 pandemic. This causes low students activeness and learning outcomes. The purpose of this study was to increase students' activeness and learning outcomes in the classroom through the media of songs. Furthermore, this research was to increase students' learning outcomes. The research method used was Classroom Action Research (CAR) with the model used by Kemmis \& Tagart. The object of the research was students of class $3 B$ with a total of 21 students at Saint John Christian Elementary School in Indonesian Language subject. Data collection using an assessment rubric to measure student activity and a test to measure student learning outcomes. Data were analyzed descriptively. The results obtained on student activeness were that students who were categorized as very active and active reached $90 \%$ of students in the second cycle. On student learning outcomes, the results obtained are students who get complete results on student learning outcomes in the pre-cycle are $50 \%$ of students, in cycle 1 there are $89 \%$ of students and in cycle 2 are $91 \%$. From these results, it has exceeded the target of the target, which should be $90 \%$ of students complete their learning outcomes. The conclusion is song learning media is able to increase students' activeness and learning outcomes. This research is suggested for the teachers to use song learning media to increase student activeness and student learning outcomes.
\end{abstract}

Keywords: students activeness, learning outcomes, song learning media

\section{ABSTRAK}

Penelitian ini berangkat dari permasalahan buruknya kualitas pembelajaran online yang dilakukan guru sejak pandemi Covid-19. Hal ini menyebabkan keaktifan dan hasil belajar siswa rendah. Tujuan penelitian ini adalah untuk meningkatkan keaktifan siswa di kelas dan hasil belajar siswa melalui media pembelajaran lagu. Metode penelitian yang digunakan adalah Penelitian Tindakan Kelas (PTK) dengan model yang digunakan oleh Kemmis \& Tagart. Objek penelitian ini adalah siswa kelas 3B yang berjumlah 21 siswa di SD Kristen Saint John mata pelajaran Bahasa Indonesia. Pengumpulan data menggunakan rubrik penilaian untuk mengukur aktivitas siswa dan tes untuk mengukur hasil belajar siswa. Data dianalisis secara 
deskriptif. Hasil yang diperoleh dari keaktifan siswa adalah Hasil siswa yang termasuk kategori sangat aktif dan aktif mencapai $90 \%$ siswa pada siklus 2 . Pada hasil belajar siswa, hasil yang diperoleh siswa yang memperoleh hasil ketuntasan pada hasil belajar siswa pada prasiklus sebanyak 50\% siswa, pada siklus 1 terdapat $89 \%$ siswa dan pada siklus 2 sebanyak 91\%. Dari hasil tersebut telah terlampaui target yang diharapkan yaitu $90 \%$ siswa menyelesaikan hasil belajarnya. Kesimpulannya adalah media pembelajaran lagu mampu meningkatkan keaktifan dan hasil belajar siswa. Penelitian ini menyarankan agar guru menggunakan media pembelajaran lagu untuk meningkatkan keaktifan siswa dan hasil belajar siswa.

Kata Kunci: keaktifan siswa, hasil belajar, media pembelajaran lagu

\section{A. Pendahuluan}

Pendidikan

merupakan

kebutuhan yang wajib dimiliki setiap orang. Pendidikan harus dimiliki oleh setiap orang karena sebagai kebutuhan dasar pemenuhan diri, ilmu pengetahuan semakin berkembang sehingga setiap orang yang menerima pendidikan akan maju dalam ilmu dan karakter yang merupakan prestasi saat ini. Untuk itu, Indonesia menjadikan pendidikan sebagai aspek penting yang kualitasnya harus dikembangkan dengan harapan masyarakat Indonesia akan semakin maju dalam kualitas sumber daya manusianya dalam bidang pengetahuan dan karakter.

Pernyataan ini juga sejalan dengan Undang-Undang Republik Indonesia Nomor 20 Tahun 2003 tentang Sistem Pendidikan Nasional Bab II Pasal 3 yang menyatakan bahwa pendidikan mempunyai fungsi agar peserta didik dapat mengembangkan kemampuan dan membentuk karakter bangsa yang bermartabat. dan peradaban untuk mencerdaskan kehidupan bangsa, bertujuan untuk mengembangkan potensi peserta didik menjadi manusia yang beriman dan bertakwa kepada Tuhan Yang Maha Esa, berakhlak mulia, sehat, berilmu, cakap, kreatif, mandiri dan menjadi warga negara yang demokratis. Pendidikan harus mengikuti fungsinya dalam memajukan kemampuan dan potensi ilmu serta membentuk karakter peserta didik, hal tersebut harus didukung oleh salah satu peran utama dalam memajukan pendidikan yaitu sebagai pendidik atau guru.

Dalam menjalankan program pendidikan pun tidak lepas dari peran guru dalam mempersiapkan 
Pendas : Jurnal Ilmiah Pendidikan Dasar, ISSN Cetak : 2477-2143 ISSN Online : 2548-6950 Volume VI Nomor 01, Juni 2021

pembelajaran dengan proses yang baik. Pembelajaran yang baik adalah pembelajaran yang telah mencapai tujuan pembelajaran dengan proses yang dirumuskan oleh guru. Dalam kegiatan pembelajaran ini terdapat interaksi antara guru dan siswa. Pembelajaran biasanya dilakukan langsung di dalam kelas atau di luar kelas dan dilakukan secara tatap muka secara langsung.

Nyatanya, tidak semua kondisi bisa dilakukan pembelajaran tatap muka secara langsung. Kondisi tersebut dialami pada saat pandemi yang dialami mulai Maret 2020 melanda seluruh dunia, termasuk Indonesia. Wabah pandemi akibat Covid-19 menyebabkan terhentinya kegiatan belajar mengajar atau belajar tatap muka di sekolah karena harus menjaga jarak atau jarak fisik. Wabah virus Covid-19 dapat menular langsung melalui kontak fisik.

Kondisi ini menjadi masalah bagi guru dan siswa karena semua kegiatan pembelajaran dibatasi, termasuk kegiatan tatap muka dengan siswa. Pembelajaran jarak jauh berarti bahwa siswa harus belajar di rumah dan guru juga mengajar dari rumah. Kondisi tersebut menuntut guru untuk menjadikan inovasi pembelajaran sebagai langkah yang tepat agar setiap siswa tetap dapat memperoleh pembelajaran pada saat kondisi seperti ini. Salah satu yang bisa dilakukan adalah dengan melakukan pembelajaran online.

Pembelajaran secara online adalah pembelajaran yang memanfaatkan penggunaan jaringan internet. Pembelajaran secara online adalah pembelajaran dengan menggunakan jaringan web yang didalamnya terdapat materi dalam bentuk video dan pemberian tugastugas kepad siswa (Tsabit et al., 2020). Dengan pembelajaran online, siswa dapat belajar dimanapun dan kapanpun. Siswa dan guru dapat berinteraksi meskipun jaraknya sangat jauh dengan menggunakan internet. Pembelajaran online dapat menggunakan beberapa aplikasi, seperti google classroom dan whatsapp group. Tidak hanya dua aplikasi tersebut yang mungkin sudah banyak digunakan, guru dan siswa juga dapat bertatap muka secara online melalui aplikasi zoom dan google meet. Diungkapkan Dewi, pembelajaran secara online merupakan inovasi yang dapat dilakukan guru untuk menjawab tantangan ketersediaan berbagai 
Pendas : Jurnal Ilmiah Pendidikan Dasar, ISSN Cetak : 2477-2143 ISSN Online : 2548-6950 Volume VI Nomor 01, Juni 2021

sumber dan model pembelajaran. Pembelajaran online merupakan jawaban atas permasalahan bagi guru ketika situasi dan kondisi membutuhkan batasan. (Dewi, 2020)

Pembelajaran online yang dilakukan dapat mempengaruhi banyak hal seperti minat belajar dan fokus belajar siswa dan tidak hanya itu, pembelajaran online akan mempengaruhi penentuan dari penggunaan metode dan media pembelajaran yang tepat. Fokus pembelajaran siswa dan minat siswa dalam pembelajaran, serta metode dan media pembelajaran sangat erat kaitannya. Jika guru salah memilih metode dan media pembelajaran maka akan berdampak pada berkurangnya minat dan fokus belajar siswa. Fokus dan minat belajar siswa akan mempengaruhi hasil belajar siswa

SD Kristen Saint John Bekasi telah melakukan pembelajaran online selama pandemi Covid-19. Dalam pelaksanaan pembelajaran online di SD Kristen Saint John Bekasi terbagi menjadi dua cara penyelenggaraan pembelajaran yaitu Synchronous dan Asynchronous.

Tahap synchronous adalah pembelajaran tatap muka secara virtual menggunakan aplikasi Zoom Meeting. Asynchronous adalah pembelajaran tanpa tatap muka dan tidak menggunakan aplikasi Zoom Meeting tetapi menggunakan Google Classroom dengan mengirimkan materi, video pembelajaran, dan memberikan tugas kepada siswa. Beberapa guru masih menggunakan metode konvensional yaitu ceramah, dimana guru hanya menjelaskan materi saja tanpa dukungan media pembelajaran apapun pada saat melakukan aspek pembelajaran Sychronous. Dampaknya, beberapa siswa kurang antusias mengikuti pembelajaran yang dilaksanakan. Beberapa siswa mematikan kamera mereka selama pembelajaran dan bahkan tidak mengikuti kelas.

Pada aspek pembelajaran Asynchronous, beberapa guru hanya mengirimkan tugas menggunakan aplikasi Google Classroom dan meminta aktifitas siswa untuk menyelesaikannya dan kemudian mengirimkan hasil yang sudah dikerjakan. Tidak hanya tugas, guru juga mengirimkan materi melalui Google Classroom tanpa ada penjelasan dari guru tentang materi tersebut. Dampak dari penggunaan metode konvensional dan kurangnya 
Pendas : Jurnal Ilmiah Pendidikan Dasar, ISSN Cetak : 2477-2143 ISSN Online : 2548-6950 Volume VI Nomor 01, Juni 2021

media pembelajaran oleh guru sehingga siswa kurang aktif dan menurunkan minat dan semangat siswa untuk belajar.

Dari dua cara penyampaian materi, siswa membutuhkan media pembelajaran untuk membantu guru menyampaikan materi. Media pembelajaran juga membantu agar siswa memiliki semangat belajar dan dapat mempengaruhi hasil belajar siswa yang lebih baik. Lagu dapat menjadi solusi yang tepat untuk mengembalikan minat belajar siswa. Melalui lagu dan nyanyian serta melibatkan lagu dalam pembelajaran akan membantu siswa dalam memahami pembelajaran dan bermanfaat dalam merangsang $I Q$ dan SQ EQ siswa (Wadiyo, 2015) yang sangat dibutuhkan dalam perkembangan usia siswa sekolah dasar.

Bernyanyi menggunakan lagu dan melibatkannya dalam setiap pembelajaran juga dapat membantu proses kegiatan pembelajaran, sehingga pembelajaran di kelas akan mencapai tujuannya dan mengikuti perkembangan anak (Utomo \& Azimah, 2018). Sehingga kegiatan pembelajaran berhasil jika siswa mampu menangkap setiap materi pembelajaran yang diajarkan guru dengan konsep yang benar.

Terkadang proses kegiatan belajar mengajar sering mengalami kendala terutama dalam pembelajaran bahasa Indonesia. Siswa kesulitan memahami belajar bahasa Indonesia. Sampai saat ini, guru SD Kristen Saint John menggunakan metode konvensional seperti ceramah dan menulis. Sedangkan dengan metode ceramah dan menulis saja sudah dapat mengurangi semangat mahasiswa. Padahal, siswa di Indonesia diharapkan memiliki empat kemampuan berbahasa, yaitu menulis, membaca, menyimak, dan berbicara. Pembelajaran siswa dan dapat mengurangi keaktifan siswa di kelas terhadap pelajaran bahasa Indonesia dan berakibat pada penurunan hasil belajar siswa.

Oleh karena itu, perlu adanya variasi pembelajaran di kelas yang efektif seperti penggunaan media pembelajaran lagu yang diharapkan dapat mempengaruhi permasalahan yang terjadi pada setiap kondisi seperti pandemi Covid-19 dan apakah media pembelajaran lagu tersebut akan mempengaruhi keaktifan dan hasil belajar. Hasil belajar yang 
Pendas : Jurnal Ilmiah Pendidikan Dasar, ISSN Cetak : 2477-2143 ISSN Online : 2548-6950 Volume VI Nomor 01, Juni 2021

dimaksud adalah penilaian dalam bentuk nilai, simbol, angka dan kata (Handayani, 2019)

Dari uraian tersebut, maka peneliti bermaksud untuk melakukan penelitian untuk mengetahui pengaruh penggunaan media pembelajaran lagu dalam pembelajaran bahasa Indonesia khususnya terhadap materi perubahan wujud benda dengan objek di kelas 3. Peneliti melakukan penelitian sebagai guru di kelas 3 yang mengajar mata pelajaran bahasa Indonesia di SD Kristen Saint John Bekasi.

\section{B. Metode Penelitian}

Penelitian ini merupakan penelitian Tindakan Kelas (PTK) dengan model Kemmis dan Taggart. Penelitian Tindakan Kelas merupakan strategi dalam memecahkan masalah dengan melakukan tindakan nyata dan peningkatan kapasitas. Penelitian Tindakan Kelas (PTK) pada model kemmis tagart terdiri dari empat strategi yaitu rencana tindakan, pelaksanaan, observasi dan refleksi. Dalam penelitian ini Penelitian Tindakan Kelas (PTK) digunakan untuk mengetahui apakah media pembelajaran lagu dapat memberikan peningkatan keaktifan siswa dan hasil belajar siswa.

Penelitian Tindakan Kelas (PTK) model Kemmis \& Tagart dapat digambarkan sebagai berikut:

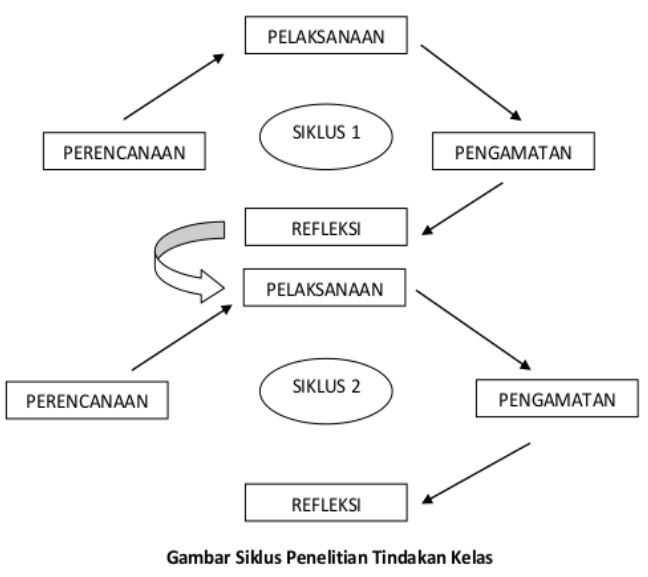

Gambar 1 Desain PTK Kemmis \& M.C Tagart

\section{Perencanaan}

Peneliti perencanaan tindakan melaksanakan aktifitas rangkaian perencanaan dan persiapan pelaksanaan penelitian yang diawali dengan mengamati proses pembelajaran yang terjadi, kemudian membuat RPP, membuat jadwal, membuat lagu yang digunakan sebagai media pembelajaran, menyiapkan perangkat pembelajaran, membuat instrumen penilaian untuk pembelajaran awal. tes siklus, tes siklus 1 dan siklus 2 kemudian membuat instrumen penilaian untuk menilai keaktifan siswa. Penelitian ini dilakukan pada materi pelajaran 
Pendas : Jurnal IImiah Pendidikan Dasar, ISSN Cetak : 2477-2143 ISSN Online : 2548-6950 Volume VI Nomor 01, Juni 2021

bahasa Indonesia tentang materi perubahan wujud benda. Jadi, lagulagu yang dibuat ditujukan untuk perubahan materi kenegaraan

Lagu yang digunakan sebagai media pembelajaran yang berjudul "Berubah Wujud" dengan lirik sebagai berikut:

Padat jadi cair namanya mencair Cair jadi padat namanya membeku Padat jadi gas namanya menyublim Gas jadi padat mengkristal namanya Gas jadi cair namanya menyembun Cair jaadi gas namanya menguap Itu semua perubahan wujud Gas, Cair, Padat berubah wujud

\section{Tindakan}

Peneliti melakukan tindakan terhadap materi pembelajaran bahasa Indonesia tentang perubahan negara. Peneliti membaginya menjadi dua pertemuan konferensi melalui aplikasi zoom. Peneliti melakukan tindakan dengan memberikan pembelajaran dari RPP yang telah dibuat sebelumnya dan pre test. Pre-test diberikan kepada siswa untuk mengetahui pengetahuan awal perubahan materi pembelajaran dalam bentuk soal yang harus diisi selama 30 menit pada pertemuan pertama.
Pelajaran dilakukan dalam dua kali pertemuan. Pada pertemuan pertama dilakukan pre-test kemudian dilanjutkan dengan pembelajaran yaitu mengenalkan perubahan wujud benda, bagan perubahan wujud benda, kemudian mengajarkan lagu mengubah bentuk benda. Setelah itu peneliti yang juga guru ini mengajarkan perubahan berupa benda-benda yang mencair dan membeku. Kemudian siswa diminta untuk mencari informasi yang terdapat dalam sebuah teks tentang bendabenda yang mencair dan membeku serta menuliskannya di buku tugas. Selanjutnya, siswa bereksperimen benda mencair dan membeku dengan mengamati perubahan pada es batu jika diletakkan di ruangan yang suhunya tidak dingin. Kemudian siswa praktek membuat es batu dan hasil prakteknya diserahkan ke google classroom. Sesi terakhir siswa menyanyikan lagu Berubah Wujud bersama. Kemudian pelajaran ditutup dengan doa.

Pada pertemuan kedua, siswa dan guru melakukan apersepsi sebelum pembelajaran dimulai. Kemudian siswa bersama guru menyanyikan lagu Berubah Wujud, kemudian guru memilih beberapa 
Pendas : Jurnal IImiah Pendidikan Dasar, ISSN Cetak : 2477-2143 ISSN Online : 2548-6950 Volume VI Nomor 01, Juni 2021

siswa untuk menyanyikan lagu tersebut. Setelah itu dilanjutkan dengan pembelajaran yaitu menyusun paragraf menjadi teks tentang menyublim. Kemudian, siswa dan guru berdiskusi bersama tentang menyublim dan mengkristal dari teks yang telah disusun. Setelah itu siswa diminta untuk menyimpulkan informasi dari teks tersebut. Setelah pembelajaran selesai, dipilih satu siswa untuk memimpin doa.

\section{Pengamatan}

Pengamatan dilakukan dalam dua jenis, yaitu mengamati keaktifan siswa selama proses pembelajaran dan melakukan penilaian siklus 1 dengan memberikan soal pilihan ganda kepada siswa melalui google classroom untuk mengukur hasil belajar siswa.

\section{Evaluasi}

Peneliti mengevaluasi hasil observasi yang dilakukan apakah dapat dilanjutkan ke siklus selanjutnya atau tidak. Penelitian ini dilaksanakan di SD Kristen Saint John yang berlokasi di Jalan Kemuning Indah Blok HH, Pejuang, Medan Satria, RT.004 / RW.019, Pejuang, Kecamatan Medan Satria, Kota Bekasi, Jawa Barat 17131. SD Kristen Saint John Bekasi merupakan sekolah swasta yang mengintegrasikan setiap pembelajaran dengan nilai-nilai Kristiani. Sekolah ini menggunakan kurikulum 2013.

Penelitian ini dilaksanakan pada hari Selasa 20 Oktober 2020 - Jumat 30 Oktober 2020. Berikut adalah jadwalnya:

Tabel 1 Jadwal Pelaksanaan Penelitian

\begin{tabular}{|c|c|c|}
\hline \multicolumn{3}{|c|}{ JADWAL PELAKSANAAN PENELITIAN } \\
\hline No & Nama Kegiatan & $\begin{array}{c}\text { Waktu } \\
\text { Pelaksanaan }\end{array}$ \\
\hline \multicolumn{3}{|c|}{ Siklus 1} \\
\hline 1 & $\begin{array}{l}\text { Pretest } \\
\text { Pengenalan } \\
\text { "Perubahan Wujud } \\
\text { Benda" } \\
\text { Pengenalan lagu } \\
\text { "Berubah Wujud" } \\
\text { Materi } 1 \text { : Mencair } \\
\text { dan Membeku }\end{array}$ & $\begin{array}{l}\text { Selasa, } \\
20 / 10 / 2020\end{array}$ \\
\hline 2 & $\begin{array}{l}\text { Latihan lagu } \\
\text { "Berubah Wujud" } \\
\text { Material 2: } \\
\text { Menyublim dan } \\
\text { Mengkristal }\end{array}$ & $\begin{array}{c}\text { Kamis, } \\
22 / 10 / 2020\end{array}$ \\
\hline 3 & Test Siklus 1 & $\begin{array}{c}\text { Jumat, } \\
23 / 10 / 2020\end{array}$ \\
\hline \multicolumn{3}{|c|}{ Siklus 2} \\
\hline 4 & $\begin{array}{l}\text { Bernyanyi lagu } \\
\text { "Berubah Wujud" } \\
\text { Materi } 3 \text { : } \\
\text { Mengembun }\end{array}$ & $\begin{array}{c}\text { Senin, } \\
26 / 10 / 2020\end{array}$ \\
\hline 5 & $\begin{array}{l}\text { Bernyanyi lagu “" } \\
\text { Berubah Wujud" } \\
\text { Materi } 4 \text { : } \\
\text { Menquap }\end{array}$ & $\begin{array}{l}\text { Selasa, } \\
27 / 10 / 2020\end{array}$ \\
\hline 6 & Test Siklus 2 & $\begin{array}{l}\text { Jumat, } \\
30 / 10 / 2020\end{array}$ \\
\hline
\end{tabular}

Partisipan yang menjadi objek dalam penelitian ini adalah siswa SD Kristen Saint John Bekasi dengan cluster sampling yaitu kelas 3B. Jumlah siswa kelas 3B sebanyak 21 
siswa dengan 11 siswa dan 10 siswi.

Dalam pengumpulan data dilakukan dengan beberapa teknis dan method.

Pengumpulan data yang pertama dilakukan dengan menilai keaktifan siswa melalui rubrik observasi dengan cara melakukan pengamatan langsung di dalam kelas selama pembelajaran. Rubrik ini memiliki indikator yaitu kehadiran siswa, keaktifan selama pembelajaran dan penerapan pembelajaran.

Tabel 2 Rubrik Indikator

\begin{tabular}{llcc}
\hline No & \multicolumn{1}{c}{ Indikator } & Jumlah & Nomor \\
\hline 1 & $\begin{array}{l}\text { Kehadiran } \\
\text { siswa }\end{array}$ & 2 & 1,2 \\
\hline 2 & $\begin{array}{l}\text { Keaktifan } \\
\text { selama } \\
\text { pembelajaran }\end{array}$ & 6 & $\begin{array}{c}2,3,4,5,6,7, \\
\text { dan 8 }\end{array}$ \\
\hline 3 & $\begin{array}{l}\text { Penerapan } \\
\text { pembelajaran }\end{array}$ & 2 & 9,10 \\
\hline
\end{tabular}

Pengumpulan data dilakukan dengan memberikan tes untuk mengukur hasil belajar siswa. Tes yang dilakukan adalah memberikan pertanyaan tentang perubahan bentuk benda yang dilakukan pada prasiklus, siklus I dan siklus II. Pada prasiklus dilakukan dengan pemberian soal pengisian. Pada siklus I dilakukan pemberian soal pilihan ganda. Pada siklus kedua dilakukan dengan pemberian tes pilihan ganda dan uraian, sehingga hal ini menjadikan pilihan ganda sebagai instrument. .
Dalam penelitian ini data akan dianalisis dengan menggunakan teknik deskriptif. Teknik yang digunakan adalah membandingkan hasil keaktifan siswa dua siklus dengan hasil belajar siswa. Siklus akan berhenti jika hasil belajar mencapai kriteria ketuntasan belajar minimal. Dalam penelitian ini kriteria tujuan adalah $90 \%$ dari jumlah siswa yang lulus kriteria Ketuntasan Belajar Minimal (KBM). Kriteria sasaran adalah $90 \%$ karena $10 \%$ siswa dibatasi dalam penggunaan perangkat sehingga penelitian ini tidak dapat mencapai $100 \%$. Kriteria Ketuntasan Belajar Minimal (KBM) untuk Bahasa Indonesia adalah 65.

\section{C.Hasil Penelitian dan Pembahasan}

Penelitian dilakukan di Sekolah Dasar Kristen Saint John yang merupakan sekolah Kristen swasta. Sekolah ini mengutamakan pendidikan yang terintegrasi dengan nilai-nilai Kristiani. Penelitian ini dilakukan sesuai dengan rencana yang telah dibuat namun dengan beberapa perubahan. Perubahan terjadi dalam hal penggantian media pembelajaran tambahan. Penyebab perubahan karena kondisi yang tidak memungkinkan karena terhalang 
Pendas : Jurnal IImiah Pendidikan Dasar,

jaringan. Berikut proses yang telah dilakukan dalam penelitian ini dan hasil dari penelitian ini.

\section{Proses Tindakan}

Penelitian ini dibagi menjadi dua siklus. Dari dua siklus tersebut, setiap siklus dibagi menjadi dua pertemuan. Siklus 1

- Perencanaan

Pada tahap perencanaan, peneliti menyiapkan RPP, menyiapkan lagu sebagai media pembelajaran, menyusun rubrik penilaian keaktifan siswa dan hasil belajar siswa. Pada tahap ini peneliti juga membuat jadwal pelaksanaan tindakan yang akan dilakukan, menyiapkan izin sekolah dan menyiapkan perangkat pembelajaran. Penelitian ini dilakukan pada pembelajaran Bahasa Indonesia pada Tema 3: Benda di Sekitarku pada Sub Tema 3: Perubahan Wujud Benda.

\section{- Aksi/Pelaksanaan}

Pada tahap tindakan peneliti melakukan dua kali pertemuan yaitu pada tanggal 20 November 2020 dan 22 November 2020 yang dilakukan dengan pertemuan virtual menggunakan aplikasi zoom.

Setelah melalui serangkaian pembelajaran, peneliti membuat tes formatif siklus I dengan tujuan untuk mengetahui pengetahuan siswa tentang materi perubahan bentuk benda. Tes formatif yang diberikan berupa 20 item pilihan ganda yang akan dilaksanakan pada hari Jumat, 23 Oktober 2020 melalui aplikasi google classroom.

- Pengamatan

Peneliti melakukan observasi keaktifan siswa dan hasil belajar siswa. Mengenai keaktifan siswa, peneliti melakukan observasi selama pembelajaran dan melihat kembali rekaman video pelajaran yang telah direkam sebelumnya. Terhadap hasil belajar siswa, peneliti melihat hasil yang telah dilakukan pada pre-test dan tes formatif.

- Evaluasi

Dalam evaluasi dilakukan analisis terhadap hasil observasi keaktifan siswa dan hasil belajar dari instrumen yang ada. Ditemukan bahwa siswa mengalami peningkatan pemahaman tentang perubahan keadaan tetapi belum mencapai target. Maka penelitian ini dilanjutkan ke siklus 2.

Siklus 2

- Perencanaan

Dari hasil siklus I ditemukan bahwa beberapa siswa masih belum 
Pendas : Jurnal Ilmiah Pendidikan Dasar, ISSN Cetak : 2477-2143 ISSN Online : 2548-6950 Volume VI Nomor 01, Juni 2021

mengalami peningkatan kreativitas dan hasil belajar siswa sehingga perlu adanya peningkatan. Peneliti kemudian membuat gerakan. Gerakan dibuat sederhana dan mudah dipahami oleh siswa. Gerakan dimaksudkan untuk merepresentasikan perkataan dari benda-benda yang terdapat pada lagu tersebut yaitu wujud benda cair, padat dan gas.

- Aksi/Pelaksanaan

Pertemuan selanjutnya dilaksanakan pada hari Senin tanggal 26 Oktober 2020. Pada pertemuan ini peneliti melakukan pengejaran gerak kepada mahasiswa dan diiringi lagu. Beberapa siswa diminta oleh peneliti untuk menyanyikan lagu "Berubah Wujud". Pelajaran dilanjutkan dengan mengidentifikasi proses membeku. Pada pertemuan ini peneliti tiba-tiba mengganti media pembelajaran dan metode pengajaran yang seharusnya mendemonstrasikan

proses kondensasi dengan menggunakan beberapa alat dan bahan kemudian diganti dengan video karena waktu dan beberapa peralatan tidak tersedia. Video yang ditayangkan kepada siswa berjudul "Mengapa Embun Terbentuk?" melalui platform Youtube. Kemudian siswa membaca teks yang berjudul "Mengembun" dan menemukan beberapa kata baku kemudian peneliti mengajarkan cara menggunakan Kamus Besar Bahasa Indonesia (KBBI) secara online dan mencari beberapa arti dari kata baku. Setelah itu siswa diminta membuat kalimat dari kata-kata tersebut.

- Pengamatan

Peneliti melakukan observasi terhadap kreativitas siswa dan hasil belajar siswa. Mengenai keaktifan siswa, peneliti melakukan observasi selama pembelajaran dan melihat kembali pelajaran video rekaman yang telah direkam sebelumnya. Terhadap hasil belajar siswa, peneliti melihat hasil yang telah dilakukan pada pre-test dan tes formatif.

\section{Hasil Tindakan}

Berikut ini adalah hasil dari tindakan yang telah dilakukan:

- Pra-siklus

Pada pra-siklus dilakukan pretest dengan pemberian soal dan ditemukan $50 \%$ belum mencapai kriteria belajar minimal yaitu 11 siswa dan 10 siswa yang telah mencapai kriteria belajar minimal. Kriteria belajar minimal (KBM) adalah 65.

- Siklus 1 
Pendas : Jurnal Ilmiah Pendidikan Dasar, ISSN Cetak : 2477-2143 ISSN Online : 2548-6950

Volume VI Nomor 01, Juni 2021

Pada akhir siklus I, keaktifan siswa dan hasil belajar siswa dinilai. Dalam keaktifan siswa ditemukan $60 \%$ siswa sangat aktif dan sudah memenuhi indikator, 20\% siswa aktif, dan $20 \%$ siswa kurang aktif atau cukup aktif. Pada hasil belajar siswa ditemukan $89 \%$ siswa telah mencapai kriteria belajar minimal dan $21 \%$ siswa belum mencapai kriteria belajar minimal.

\section{- Siklus 2}

Pada siklus 2 juga dilakukan penilaian keaktifan dan hasil belajar siswa. Dalam keaktifan siswa ditemukan $71 \%$ siswa sangat aktif, 19\% siswa aktif dan 10\% siswa tidak aktif atau cukup. Pada hasil belajar siswa terdapat $91 \%$ yang mencapai kriteria belajar minimal dan $9 \%$ yang tidak mencapai kriteria belajar minimal.

\section{Perbandingan}

Dari hasil tindakan tersebut, telah dilakukan perbandingan keaktifan siswa dan hasil belajar siswa sehingga diperoleh hasil perbandingan sebagai berikut:

\section{Tabel 3 Penilaian Kekaktifan Siswa}

\section{Keaktifan Siswa}

\begin{tabular}{ccc}
\hline Perbandingan & Cycle 1 & Cycle 2 \\
\hline Sangat Aktif & $60 \%$ & $71 \%$
\end{tabular}

\begin{tabular}{ccc}
\hline \multicolumn{3}{c}{ Keaktifan Siswa } \\
\hline Aktif & $20 \%$ & $19 \%$ \\
\hline Cukup & $20 \%$ & $10 \%$ \\
\hline
\end{tabular}

Tabel di atas menunjukkan bahwa siswa yang sangat aktif pada siklus I sebanyak $60 \%$ siswa dan pada siklus II sebanyak $71 \%$ siswa. Siswa yang ingin aktif pada siklus I sebanyak $20 \%$ pada siklus I dan $19 \%$ pada siklus II. Hasil penelitian menunjukkan bahwa siswa yang termasuk kategori sangat aktif dan aktif mencapai 90\% siswa pada siklus II. Dari hasil tersebut peneliti tidak melanjutkan siklus berikutnya karena telah mencapai target yang direncanakan.

Tabel 4 Penilaian Hasil Belajar

\begin{tabular}{cccc}
\hline & \multicolumn{3}{c}{ Hasil Belajar } \\
\hline Ketuntasan & $\begin{array}{c}\text { Pra- } \\
\text { Siklus }\end{array}$ & $\begin{array}{c}\text { Siklus } \\
\text { Siklus }\end{array}$ & 2 \\
\hline $\begin{array}{c}\text { Tidak } \\
\text { Tuntas }\end{array}$ & $50 \%$ & $21 \%$ & $9 \%$ \\
\hline Tuntas & $50 \%$ & $89 \%$ & $91 \%$ \\
\hline Jumlah & $100 \%$ & $100 \%$ & $100 \%$ \\
\hline
\end{tabular}

Berdasarkan tabel di atas diketahui bahwa hasil siswa yang memperoleh hasil ketuntasan terhadap hasil belajar siswa pada prasiklus adalah $50 \%$ siswa, pada siklus 1 terdapat $89 \%$ siswa dan pada siklus 2 sebanyak 91\%. Dari hasil 
Pendas : Jurnal Ilmiah Pendidikan Dasar, ISSN Cetak : 2477-2143 ISSN Online : 2548-6950 Volume VI Nomor 01, Juni 2021

tersebut telah melampaui target yang diharapkan yaitu $90 \%$ siswa menyelesaikan hasil belajarnya.

\section{Diskusi}

Hasil penelitian ini menunjukkan bahwa dengan penyediaan media pembelajaran lagu pada materi tertentu dapat meningkatkan keaktifan siswa dan hasil belajar siswa. Hasil penelitian ini juga sejalan dengan beberapa penelitian sebelumnya. Hasil ini sejalan dengan Sandri yang menemukan bahwa lagu dapat memberikan pengaruh pada pembelajaran materi matematika pada sifat-sifat bangun datar pada siswa kelas 5 SD Negeri 5 Bengkulu. Hasil penelitian ini dengan rata-rata nilai kelas eksperimen 72.04 dan nilai rata-rata 62.40 untuk siswa kontrol. Artinya media pembelajaran Lagu dapat meningkatkan hasil belajar siswa (Sandri, 2018). Dibandingkan dengan penelitian ini. hasil penelitian dari Sandri sejalan dengan penelitian ini. Kedua penelitian tersebut dapat meningkatkan hasil belajar siswa.

Hal ini juga sejalan dengan penelitian yang dilakukan oleh Anggraeni bahwa media lagu anak dapat memberikan peningkatan hasil belajar siswa dalam menulis puisi.
Hasil penelitian dapat dilihat dari hasil belajar prasiklus yang memiliki nilai rata-rata 53,67 sampai dengan 70,17 pada siklus II (Anggraeni, 2016). Dibandingkan dengan penelitian ini, penelitian dari Anggraeni sejalan dengan penelitian ini. Kedua penelitian tersebut dapat meningkatkan hasil belajar siswa.

Selain itu, hal ini juga sejalan dengan penelitian yang dilakukan oleh Suriyana et al. yang ditemukan melalui penelitian pengembangan bahwa media pembelajaran matematika berbasis lagu sangat efektif. Hasil evaluasi penelitian pengembangan memiliki nilai mean 4 (Suriyana et al., 2020). Penelitian yang dilakukan oleh Suriyana et al juga sejalan dengan penelitian ini dengan hasil media pembelajaran lagu efektif untuk pembelajaran.

\section{Kesimpulan}

Dari hasil penelitian tindakan kelas (PTK) yang telah dilakukan di SD Kristen Saint John Bekasi dapat disimpulkan bahwa: 1. Penggunaan lagu sebagai media pembelajaran dalam pembelajaran dapat memberikan dampak peningkatan keaktifan siswa di kelas pembelajaran virtual maupun online. 2. Penggunaan 
lagu sebagai media pembelajaran dapat memberikan dampak peningkatan hasil belajar di kelas virtual maupun pembelajaran online.

Berdasarkan hasil Penelitian Tindakan Kelas (PTK) yang telah dilaksanakan terdapat rekomendasi yang dapat diberikan yaitu Guru disarankan menggunakan media pembelajaran yaitu lagu untuk meningkatkan keaktifan siswa dan hasil belajar siswa. Siswa dapat menggunakan lagu untuk membantu siswa dalam memahami materi pembelajaran. Peneliti selanjutnya menyarankan untuk mencoba media ini di mata pelajaran atau kelas lain untuk memvalidasi keefektifan media ini di luar subjek penelitian ini.

\section{DAFTAR PUSTAKA}

Anggraeni, S. W. (2016). Penggunaan media lagu anak dalam meningkatkan hasil pembelajaran menulis puisi. 1(1), 49-60.

Dewi, W. A. F. (2020). Dampak COVID-19 terhadap Implementasi Pembelajaran Daring di Sekolah Dasar. Edukatif: Jurnal IImu Pendidikan, 2(1), 55-61. https://doi.org/10.31004/edukatif.v2 i1.89

Handayani, H. (2019). Analisis Motivasi Belajar tehadap Hasil Belajar Siswa pada Materi Globalisasi Mata Pelajaran PKN
Kelas IV SDN 4 Tapan Tahun Ajaran 2017/2018. PENDAS: Jurnal IImiah Pendidikan Dasar, 8(5), 55.

Sandri, M. (2018). Pengaruh media lagu terhadap hasil belajar matematika pada materi sifat-sifat bangun datar. 2(1), 1-8.

Suriyana, Asmah, S. N., \& Kurniawati, D. (2020). Inovasi media pembelajaran matematika berbasis lagu di sekolah dasar. 2(1), 35-47.

Tsabit, D., Rizqia Amalia, A., \& Hamdani Maula, L. (2020). Analisis Pemahaman Konsep Ips Materi Kegiatan Ekonomi Menggunakan Video Pembelajaran Ips Sistem Daring Di Kelas Iv.3 Sdn Pakujajar Cbm. Pendas: Jurnal Ilmiah Pendidikan Dasar, V(Vol 5 No 1 June 2020). https://doi.org/10.23969/jp.v5i1.291 7

Utomo, U., \& Azimah, N. (2018). Kreativitas Guru Dalam Menggunakan Lagu-Lagu Pada Pembelajaran Tematik Di Sekolah Dasar. Seni Musik, 7(1), 25-33.

Wadiyo, W. (2015). Music As An Integrated Education Tool for Preschool Students. Harmonia: Journal of Arts Research and Education, 15(2), 144-151. https://doi.org/10.15294/harmonia. v15i2.4691 